Situmorang et al./ Association between perceived seriousness, cues to action

\title{
Association between Perceived Seriousness, Cues to Action, and Voluntary Counseling and Testing Uptake in Men Who Have Sex with Men in Pematangsiantar, North Sumatera
}

\author{
Lambok Nita Situmorang, Lita Sri Andayani, Linda T Maaas
}

Masters Program in Public Health, Universitas Sumatera Utara

\begin{abstract}
Background: Utilization of voluntary counseling and testing (VCT) services in male sex with men (MSM) at Tomuan public health center, in Pematangsiantar is still relatively low (34.4\%). The low utilization of VCT services in MSM is related to the perception of seriousness and the possibility of taking action. This study aimed to analyze the influences of perceived seriousness and cues to action on the use of VCT in MSM.

Subject and Method: This was a cross sectional study carried out at Tomuan health center in Pematangsiantar, North Sumatera, in 2017. A sample of 61 MSM was selected for this study. The dependent variable was VCT use. The independent variables were perceived seriousness and cues to action. The data were obtained by questionnaire and analyzed by a multiple logistic regression.

Results: Utilization of VCT in MSM increased with perceived seriousness $(\mathrm{OR}=11.28$; $95 \% \mathrm{CI}=$ 1.24 to $102.89 ; \mathrm{p}=0.032)$ and cues to action $(\mathrm{OR}=11.45 ; 95 \% \mathrm{CI}=1.02$ to $128.34 ; \mathrm{p}=0.024)$.

Conclusion: Utilization of VCT in MSM increases with perceived seriousness and cues to action.
\end{abstract}

Keywords: perceived seriousness, VCT utilization

\section{Correspondence:}

Lambok Nita Situmorang. Masters Program in Public Health, Faculty of Public Health, Universitas Sumatera Utara, Jl. Prof. T. Maas, Medan, North Sumatera. Email: nithastmoors@gmail.com. Mobile: 085372537900.

\section{BACKGROUND}

Human Immunodeficiency Virus and Acquired Immuno Deficiency Syndrome (HIV and AIDS) are public health problems throughout the world that become a global threat. Besides, they have detrimental effect on all sectors. HIV-AIDS is an infectious disease that causes death.

The prevalence of HIV-AIDS throughout the world increases. Based on the United Nations Programme on HIV-AIDS (UNAIDS) Global Statistics (2016), the highest risk factors of HIV were risky sex towards MSM (men who have sex with men) by $28 \%$, heterosexuals by $24 \%$, others by $9 \%$, and injecting drug users by $2 \%$ (Ministry of Health RI, 2017).

North Sumatra Province is ranking $7^{\text {th }}$ in Indonesia as the largest contributor of
HIV-AIDS cases (Ministry of Health RI, 2016). It also occurred in Pematangsiantar City where the cases of this disease increased year by year. Pematangsiantar City is ranking $4^{\text {th }}$ in the discovery of HIV-AIDS cases from 33 regencies/cities in North Sumatera Province (Health Profile of the Pematangsiantar Health Office, 2017)

VCT is an important method as an early detection of HIV. It is a voluntary action that becomes an entry point in accessing the services of someone needs suffering from HIV-AIDS. They are Family Planning, psychosocial service, counseling for healthy living, mental and emotional support, legal assistance, and future planning. VCT provides treatment and support to patients in order to make them aware of their health condition early. Besides, they do not trans- 
mit it to others. This clinic collaborates with various parties in mapping, estimating, and searching for cases as early as possible, especially in high-risk groups. This case is like an iceberg phenomenon in which the actual number is estimated to far exceed the number recorded. Therefore, a positive perception of MSM towards HIV-AIDS and VCT is needed. The wrong perception will cause fear, closure, and limitations on the use of VCT services (Shaluhiyah, 2015).

There are several factors that cause people do not want to come to VCT clinic, such as the stigma of discrimination, feeling afraid that they positively have HIV, unsecured client secrets, and the distance to reach VCT services. This is in line with a study conducted by Fatmala (2016), that the use of VCT is still low due to negative perceptions of VCT. There are still many MSM who have a perception that their privacy may be unsecured. Besides, the informants are afraid of the result of the VCT test if the result is positive.

Fibriana (2012) stated that there is a significant correlation between factor of perception and the use of VCT utilization. Good perception can encourage people at high risk of HIV to do VCT. A one's perception is related to his knowledge. Someone did a VCT because they had participated in the socialization of HIV-AIDS from health workers, read posters about HIV-AIDS, and shared experiences of fellow sufferers affected by HIV-AIDS.

Based on a study conducted by Malau's (2015) on the correlation between prevention behavior and HIV among MSM in the STI (sexually transmitted Infection) Clinic and VCT Veteran Medan shows that several factors that affect the utilization of HIV testing services in STI clinic are perceived seriousness and cues to action .
Based on the preliminary survey conducted by the researcher at Pematangsiantar City Health Office, there were 550 MSM in 2017 who conducted VCT examination in Pematangsiantar City. Previously, there were $320 \mathrm{MSM}$ in 2016 who conducted VCT examination. This data shows that the number of MSM who used VCT services has not reached by $50 \%$ of the total MSM community. Therefore, the level of utilization of VCT services towards MSM communitiy in Pematangsiantar City is still relatively low. MSM do not want to use VCT services due to perceived seriousness of MSM and cues to action.

\section{SUBJECTS AND METHOD}

\section{Design of the Study}

A cross-sectional study was conducted from October 2017 to August 2018.

\section{Population and Sample}

The population of the study was all MSM who utilized VCT services in Tomuan Community Health Center, Pematangsiantar in 2017. A sample of $61 \mathrm{MSM}$ was selected by accidental sampling.

\section{Variables of the study}

The dependent variable was VCT uptake. The independent variables were perceived seriousness and cues to action.

\section{Data Analysis}

The data were analyzed by univariate, bivariate, and multivariate using a multiple logistic regression.

\begin{tabular}{l} 
RESULTS \\
\hline 1. Univariate Analysis \\
Table 1 shows the frequency distribution of \\
perceived seriousness, cues to action, and \\
the use of VCT as variables. Table 1 shows \\
that almost half of MSM had weak \\
perceived seriousness (50.8\%), weak cues \\
to action (54.1\%), and low VCT uptake \\
$(60.7 \%)$.
\end{tabular}


Table 1. Frequency Distribution

\begin{tabular}{lcc}
\hline Variables & n & \% \\
\hline Perceived Seriousness & & 49.2 \\
Strong & 30 & 50.8 \\
Weak & 31 & 45.9 \\
Cues to action & & 54.1 \\
Strong & 28 & \\
Weak & 33 & 39.3 \\
The use of VCT & & 60.7 \\
Maximum & 24 & \\
Minimum & 37 & \\
\hline
\end{tabular}

\section{Bivariate Analysis}

Table 2 shows that the utilization of VCT services towards MSM community increased with strong perceived seriousness

Table 2. The result of bivariate analysis

\begin{tabular}{|c|c|c|c|c|c|c|c|c|}
\hline \multirow{3}{*}{ Independent Variable } & \multicolumn{4}{|c|}{ The use of VCT } & & & \multirow{3}{*}{$\mathbf{O R}$} & \multirow{3}{*}{$\mathbf{p}$} \\
\hline & \multicolumn{2}{|c|}{ Good } & \multicolumn{2}{|c|}{ Poor } & \multicolumn{2}{|c|}{ Total } & & \\
\hline & $\mathbf{n}$ & $\%$ & $\mathbf{n}$ & $\%$ & $\mathbf{n}$ & $\%$ & & \\
\hline \multicolumn{9}{|l|}{ Perceived Seriousness } \\
\hline Strong & 21 & 70.0 & 9 & 30.0 & 30 & 100 & 21.78 & $<0.001$ \\
\hline Weak & 3 & 9.7 & 28 & 90.3 & 31 & 100 & & \\
\hline \multicolumn{9}{|l|}{ Cues to action } \\
\hline Good & 22 & 78.6 & 6 & 21.4 & 28 & 100 & 56.83 & $<0.001$ \\
\hline Poor & 2 & 6.1 & 31 & 93.9 & 33 & 100 & & \\
\hline
\end{tabular}

Table 3. The Result of Multiple Logistic Regression

\begin{tabular}{lrccc}
\hline \multirow{2}{*}{ Variable } & \multirow{2}{*}{$\mathbf{b}$} & \multicolumn{2}{c}{ 95\% CI } & p \\
\cline { 3 - 4 } & & Lower limit & Upper limit & \\
\hline Strong cues to action & 2.44 & 1.02 & 128.34 & 0.024 \\
High perceived seriousness & 2.42 & 1.24 & 102.89 & 0.032 \\
\hline
\end{tabular}

\section{Multivariate Analysis}

Table 3 shows the result of multiple logistic regression analysis. Table 3 shows that the utilization of VCT by MSM increased with strong cues to action $(b=2.44 ; 95 \% \mathrm{CI}=$ 1.02 to $128.34 ; \mathrm{p}=0.024)$ and high perceived seriousness $(b=2.42 ; 95 \% \mathrm{CI}=1.24$ to $102.89 ; \mathrm{p}=0.032)$.

\section{DISCUSSION}

\section{The effect of perceived seriousness on the use of VCT in MSM}

Based on the result of the study, the utilization of VCT by MSM increased with high to diseases $(\mathrm{OR}=21.78 ; \mathrm{p}<0.001)$ and strong cues to action $(\mathrm{OR}=56.83 ; \mathrm{p}$ $<0.001)$. 
Journal of Health Promotion and Behavior 4(2): 121-125

https://doi.org/10.26911/thejhpb.2019.04.02.04

seriousness of HIV. One of the variables that might affect MSM in feeling the seriousness of HIV in order to encourage themselves to use VCT in Tomuan Community Health Center in Pematangsiantar City is high level of education (Meiberg et al., 2008; Gu et al., 2015).

The perception of HIV as a deadly disease rather than a manageable chronic disease is an important cause of fear. Promoting the risk awareness and educating MSM about the benefits of HIV testing and potential intervention can help to change the balance towards MSM decision to be tested on VCT (Mikolajczak et al., 2006; Deblonde et al., 2010).

Based on a study conducted by Koh and Yong's (2014), around 60\% of study subjects have received counseling before using VCT services. As a result, they have greater awareness of the risk factors of HIV. Besides, it increases the perceived seriousness about HIV.

\section{The effect of cues to action on the use of VCT in MSM}

Based on the result of the study, the utilization of VCT by MSM increased with strong cues to action $(b=2.44 ; 95 \% \mathrm{CI}=1.02$ to 128. $34 ; \mathrm{p}=0.024$ )

The stronger the cues to action, the higher the utilization of VCT services in MSM. This study is in line with a study conducted by Wirtz et al. (2014), that MSM have awareness of the risks of HIV, but they have low ability to act on the utilization of VCT services.

There are many factors affect a person to have cues to action in utilizing VCT services, such as education, stigma, lack of support, fear of the result of HIV status, etc. (Moges and Amberbir, 2011; Buldeo and Gilbert, 2015; Workagegn et al., 2015; Nareswara et al., 2016).

\section{AUTHOR CONTRIBUTION}

Lambok Nita Situmorang selected the study subjects, collected the data, and wrote the manuscript. Lita Sri Andayani gave theoretical suggestion. Linda $\mathrm{T}$ Maaas did the data analysis and interpreted the results of data analysis.

\section{CONFLICT OF INTEREST}

There was no conflict of interest

FUNDING AND SPONSORSHIP

There was no external fund and sponsorship.

\section{ACKNOWLEDGEMENT}

We would like to thank to the Tomuan health center in Pematangsiantar, North Sumatera for giving permission to collect the data for this study.

\section{REFERENCES}

Buldeo P, Gilbert L (2015). Exploring the Health Belief Model and first-year students' responses to HIV/AIDS and VCT at a South African university. 14(3): 209-218. Retrieved from https://doi.org/10.2989/16085906.2015.1052527

Deblonde J, De Koker P, Hamers FF, Fontaine J, Luchters S, Temmerman M (2010). European Journal of Public Health. 20(4): 422-432, Retrieved from https://doi.org/10.1093/eurpub/ckp231

Fatmala RD (2015). Faktor yang Berhubungan dengan Pemanfaatan Klinik VCT oleh Laki-laki Seks dengan Lakilaki (LSL). Skripsi. Surabaya: Universitas Airlangga.

Fibriana (2012). Keikutsertaan Pelanggan Wanita Pekerja Seks dalam VCT di Resosialisasi Argorejo Semarang. Jurnal Kesehatan Masyarakat. 8(2) 
Gu J, Lau JTF, Wang Z, Wu AMS, Tan X (2015). Perceived empathy of service providers mediates the association between perceived discrimination and behavioral intention to take up hiv antibody testing again among men who have sex with men. PLoS ONE. 10(2): e0117376. Retrieved from https://doi.org/10.1371/journal.pone.0117376

Kementerian Kesehatan RI (2017). Direktorat Jenderal Pengendalian P2 dan PL. Pedoman Nasional Konseling dan Tes HIV. Jakarta.

Kementerian Kesehatan RI (2017). Direktorat Jenderal Pengendalian P2 dan PL. Pedoman Nasional Konseling dan Tes HIV. Jakarta.

Koh KC, Yong LS (2014). HIV Risk Perception, Sexual Behavior, and HIV Prevalence among Men-Who-Have-Sexwith-Men at a Community-Based Voluntary Counseling and Testing Center in Kuala Lumpur, Malaysia. Interdisciplinary Perspectives on Infectious Diseases. 236240: 6 pages. Retrieved from https://doi.org/10.1155/2014/236240.

Lawrence JS, Kelly JA, Gomez JD, Owczarzak J, Amirkhanian YA, Sitzler C (2015). Attitudes toward HIV voluntary counseling and testing (VCT) among African-american men who have sex with men: Concerns underlying reluctance to test. AIDS Educ Prev. 27(3): 195-211. Retrieved from https://dx.doi.org/10.1521\%2Faeap.2015.27.3.195.

Meiberg AE, Bos AER, Onya HE, Schaalma HP (2018). Fear of stigmatization as barrier to voluntary HIV counselling and testing in South Africa. East African Journal of Public Health. 5(2): 49-54.
Mikolajczak J, Hospers HJ, Kok G (2006). Reasons for not taking an HIV-test among untested men who have sex with men: an internet study, AIDS Behav. 10: 431-5.

Moges Z, Amberbir A (2011). Factors Associated with Readiness to VCT Service Utilization among Pregnant Women Attending Antenatal Clinics in Northwestern Ethiopia: A Health Belief Model Approach. Ethiop J Health Sci. 21(1): 107-115.

Nareswara A, Murad C, Afriandi I (2016). Health Belief Model Theory Application on Voluntary Counseling and Testing among Homosexual Men in Bandung Greater Area. Althea Medical Journal. 3(4):595-604.

Wirtz AL, Kamba D, Jumbe V, Trapence G, Gubin R, Umar E, Strömdahl SK, Beyrer C, Baral SD (2014). A qualitative assessment of health seeking practices among and provision practices for men who have sex with men in Malawi. BMC Int Health Hum Rights. 14: 20. Retrieved from https://dx.doi.org/10.1186\%2F1472-698X14-20.

Workagegn F, Kiros G, Abebe L (2015). Predictors of HIV-test utilization in PMTCT among antenatal care attendees in government health centers: institution-based cross-sectional study using health belief model in Addis Ababa, Ethiopia, 2013. HIV AIDS (Auckl). 7: 215-222. Retrieved from https://www.ncbi.nlm.nih.gov/pubmed/26203282. 